Island Studies Journal, Vol. 6, No. 2, 2011, pp. 203-226

\title{
Displacement of Youth from the Isle of Man: The Role of House Price Inflation
}

\author{
Brendan Canavan \\ Nottingham University Business School \\ United Kingdom \\ lixbc@,nottingham.ac.uk
}

\begin{abstract}
Small islands frequently suffer from population decline, especially of young people, putting continuity of community at risk. At the same time, their limited size can mean an intense competition for housing stock, particularly in scenic or economically successful islands which draw investors and migrants: a dynamic that fuels inflation. This paper investigates property inflation on the Isle of Man and its threat of displacing young inhabitants and upsetting social sustainability. Qualitative interviews with young Isle of Man émigrés and residents investigate the influences upon decisions to either remain on, or leave, the island. Whilst prices were not found to be significant in the decisions of those that have left, they were very much so for those who wished to remain. Those who have left claimed to have done so in order to improve their financial and personal options, but most did not necessarily want to leave. The overall result is distress, work disenchantment, family postponement and potentially, rising xenophobia.
\end{abstract}

Keywords: depopulation; islands; Isle of Man; property exclusion; property inflation; social sustainability; youth emigration

(C) 2011 Institute of Island Studies, University of Prince Edward Island, Canada

\section{Introduction}

Many peripheral areas, such as small islands, isolated or rural communities, are faced with the threat of depopulation (Hall et al., 2009), resulting in concern for the economic and cultural continuation of societies (Bramwell, 2004). Islands are locations where relative isolation allows unique local cultures to evolve over time, often with limited outside influence, and as a result small islands are home to distinct dialects, folklore and traditions, at the same time as strongholds for remnants of these which may have declined elsewhere. Hence depopulation, leading to ultimate abandonment of small islands, represents the loss of unique cultures evolved over hundreds of years; to illustrate, Péron (2003) discusses the death of the unique Breton Gaelic dialect which existed on Ouessant; an island off the far western tip of France. Thus, the importance of understanding factors which may contribute to population decline in small islands, in order to combat them and to ensure that their habitation remains viable into the long term.

A number of reasons for depopulation have been described in the literature (Andriotis, 2005, Royle, 2008). The limited resources of small islands are suggested as not fulfilling social, educational or financial needs and ambitions of young residents. Moreover, the limited and fragile resources typical of small islands are susceptible to rapid inflationary pressure and social change, both of which may serve to make an area less attractive for young residents. This article aims to assess the significance of property prices in young person emigration from small islands, in relation to other motivations for departure. Young person emigration is an especially important issue, as youths represent the future generations and economic base of small island communities. Furthermore, many small 


\section{B. Canavan}

islands are witnessing not just population decline, but often even more rapid rates of population ageing. For instance, the Orkney islands are an archipelago located off the northeast tip of Scotland: whilst predicting population growth to 2023, most of this is coming from retirement age people; $26 \%$ growth in this category, compared with just $4 \%$ for working age and a fall of $1 \%$ for those under the age of 15 (Orkney Economic Review, 2010).

The Isle of Man is used in this paper as the focus of a case-study on youth out-migration. As a successful small island economy experiencing population growth, there are nevertheless signs that many skilled young inhabitants of the Isle of Man are choosing not to return following higher education, which usually takes place at institutions in the United Kingdom (UK); on the island, only a limited number of degree-level courses can be undertaken at the Higher Education College. By providing detailed examples from within a community as to the perceived effects of property inflation on decisions to leave that community, it is hoped to better portray the role and influence of property prices on emigration, in order that their magnitude and impact on small island social sustainability can be assessed.

\section{The Isle of Man}

Located in the heart of the Irish Sea, between England, Ireland, Scotland and Wales, the Isle of Man has a contested history of periodic migration and rule from these larger neighbours. Local culture reflects the Celtic and Norse influences settlers brought, but also the evolution of unique local forms and traditions, created from this melange, and preserved throughout centuries of change. Perhaps the most symbolic example is the island's parliament; Tynwald, established in 979AD and the oldest continuously operational parliament in the world. Today, the Isle of Man is a self-governing crown dependency of Great Britain. Elected Tynwald members representing different island districts, have the power to pass laws affecting the island without UK interference, including tax legislation, although the British monarch still appoints a nominal head of state, the Lieutenant Governor, as its representative.

The Isle of Man population was just over 80,000 people according to the 2006 interim census, representing growth of 5\% since 2001, and 60\% since 1961 (2010 Digest). The island economy has been dominated since the 1980s by offshore finance, which in 2009 accounted for $23 \%$ of employment and 35\% of GDP (2010 Digest). It is the success of this industry which has driven rapid population growth by attracting economic and tax migrants. The tourism industry remains significant; around $10 \%$ of employment, though much declined from its post-World War II heyday. Both tourism and finance are shown to bring accompanying property inflation due to their consumption of large amounts of property and land for development purposes, and this influence can effectively displace poorer individuals and other industries over time (Hampton \& Christensen, 2007). Marcuse (1985) suggests that economies orientated towards service sectors often see a rise in gentrification, a process whereby residential neighbourhoods become more desirable and essentially middle class, often with lower income residents subsequently displaced over time. 


\section{Literature Gaps}

The literature on property inflation and its consequences upon communities is relatively narrow. Where property inflation is described, the focus is usually on the threat this may pose to natural environments through speculative development (e.g. Sharpley, 2003), not on social environmental damage. There is a lack of current original research on the topic, findings tending to be now dated or based on secondary sources (e.g. Duffield \& Long, 1981), whilst the foci of past cases have tended to be either large cities (e.g. Slater, 2008), or rural areas close to population centres (e.g. Marjavaara, 2007). Consequences of property inflation on small island social environments have been somewhat overlooked, despite their significance to community wellbeing, and the islands' uniquely difficult position regarding the maintenance of stable populations, and managing limited resources. To illustrate, results from the Jura community survey 2010, conducted on the isolated island off Scotland's west coast, mentions a housing shortage and prices as significant sources of dissatisfaction, and reasons for contemplating leaving the island amongst respondents. Despite Jura having one of the lowest population densities in Europe, and a population that has more than halved in the past century to just 300 people, outsider interest and lack of housing development funds or space, have driven prices beyond local means. At the same time the economy is highly tourism dependent and residents approve of industry expansion of the sort which may encourage further second home buyers, in order to support and create employment.

Finally, the lack of attention given to consequences of property inflation has led to contradictory findings, making consensus generation and policy making difficult. Latimer (1985) for example suggests that inflation is overemphasized, and that jobs and earnings are more significant factors in causing inhabitants to be excluded from property purchase or rental in certain areas. However, Marjavaara (2007) argues for a stronger association between incoming migrants and the exclusion from increasingly expensive property of the original inhabitants. Whilst some authors suggest that property inflation should surely benefit local residents who can make money by simply selling their property (e.g. Laws, 1995), other research understands that such gains are on paper only, for unless one moves away from the area, which people are often reluctant to do, equity released by selling property will be required to purchase another; whilst those who don't already own property; (such as the young, the less well off, the unemployed) fall further behind. Hampton and Christensen (2007) add that, whilst jobs in the finance industry may be well paid and generally keep pace with inflation, those of other sectors often do not. For example, in Jersey, mean weekly wages for finance employees were $£ 860$ in 2009, whereas for hospitality workers they were only $£ 360$ (Jersey in Figures, 2009). As a result, Buckley (2002) cautions against emerging social costs where resources in short supply are driven up in price by demand, above the range affordable to local residents who may not be lucky to enjoy well paying jobs. In addition, he emphasizes that land and housing are usually at a premium on small islands, meaning that they can be highly susceptible to inflationary pressure. Concern for the future and rising inequality is evident in research such as the Jura Community Survey, whilst Slater (2009) is highly critical of the disadvantaging of low to middle income families such economics have brought, and argues for prevailing economic assumptions to be challenged. Ayres (2000: 124) describes how, in Cyprus: “individuals with nothing to sell other than their labour power have found themselves displaced and marginalized as land and property prices have risen beyond their means." 


\section{B. Canavan}

All these contradictions are apparent on the Isle of Man, where many inhabitants have become wealthy through astute property investment. However, such a phenomenon is clearly short term, in that future generations, other than those who inherit, are left with great difficulty getting on the property ladder. Moreover, the property boom has arguably benefitted the already well off; those who were fortunate enough to have spare property to sell or cash to invest. Those with just the family home have trod water; on paper well off, but only if they move away, whilst those in rented accommodation; around $30 \%$ of Isle of Man households (2010 Digest), have moved ever further away from personal home ownership.

This paper aims to explore the reactions of community members in a small island towards property inflation, and to understand the impact this may have, if any, with regards to the potential for displacement. Although islands are far from homogenous, and therefore difficult to generalise from (Milne, 1992), the Isle of Man shares widespread island challenges of relative peripherality and isolation, limited economic development options, the threat of population loss and limited natural and physical resources including housing stock. Meanwhile, an offshore finance based economy, and accompanying concerns over population growth and property inflation, resonate with various other small island jurisdictions, particularly the Channel Islands, Bermuda, Cayman, Virgin Islands and other sub-national offshore havens.

\section{House Prices in British Small Islands}

The Isle of Man has some of the highest house prices in the British Isles; average valuation in 2009 was $£ 276,000$ (Isle of Man 2010 Digest of Economic and Social Statistics). This compares with $£ 246,000$ for the UK as a whole and with $£ 163,066$ for the Northwest region of Britain that is closest to the island (2010 prices; www.bbc.co.uk). The situation has strong parallels with that of Jersey, whose housing market is even more expensive. As one anonymous Jersey senator critiques: "The island as a whole has bugger all to show for three decades growth in the financial sector, other than a housing market which most local people cannot afford" (The Observer 2003).

A general issue facing small islands is the lack of housing and development space available. The pressure of limited housing stock can be witnessed in the Scilly Islands; a small archipelago off the southwest tip of England, which as a popular and upmarket holiday resort with an area of just $16 \mathrm{~km}^{2}$ and a year round resident population of 2,153 (www.statistics.gov.uk), subject to intense competition by incoming residents. Moreover, annual tourist numbers are around 120,000 (Southwest Tourism Report, 2008), dwarfing the permanent population. Only a small number of these need to be inspired to buy property for holiday, retirement or investment purposes, to distort the local housing market.

Figure 1 illustrates the population density of various British small islands and highlights broadly that more densely populated isles have more expensive property. While Figure 2 compares the relative size of islands to property prices, reflecting that generally those which have larger land areas have lower house prices. As might be expected, small and densely populated islands experience the strongest housing competition which in turn leads to house price inflation. 
Figure 1: Population density and mean house prices in selected British Islands, 2009.

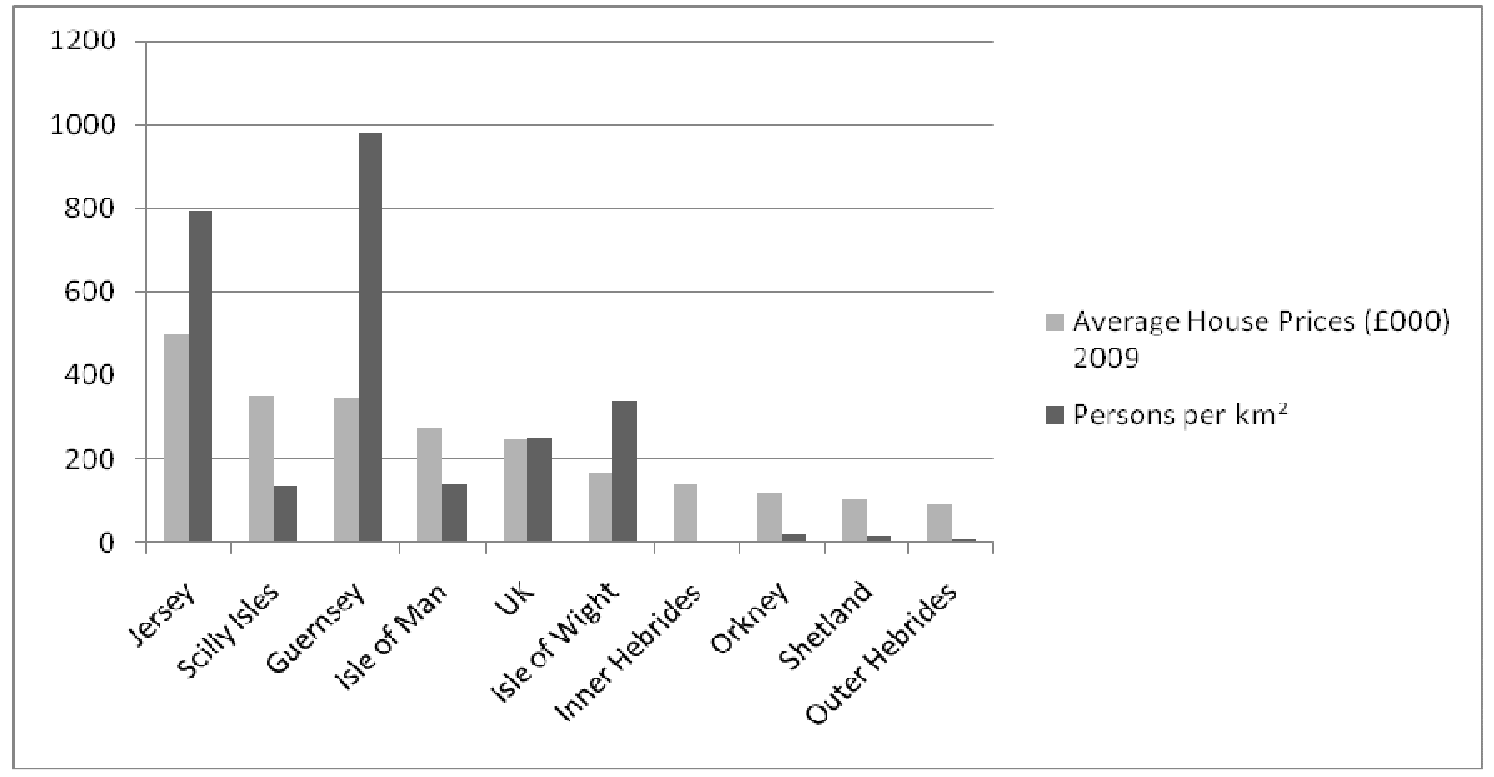

Sources: Jersey in Figures 2009, www.statistics.gov.uk, Guernsey Facts and Figures 2010, Isle of Man 2010 Digest of Economic and Social Statistics, www.bbc.co.uk, www.highland.gov.uk, Orkney Economic Review 2010, Shetland Statistics 2009, www.cne-siar.gov.uk

Figure 2: Land area and mean house prices in selected British Islands, 2009.

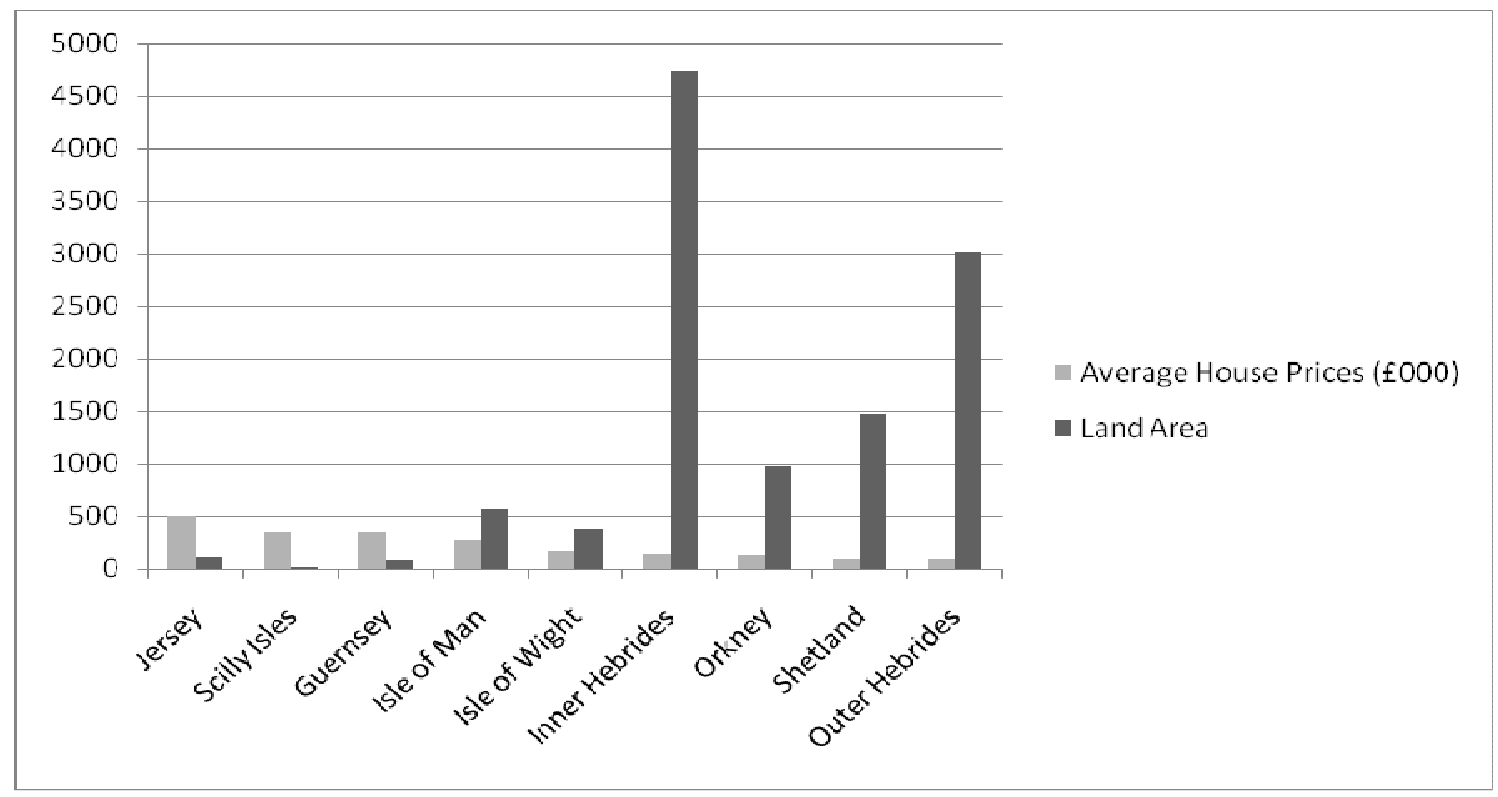

Sources: Jersey in Figures 2009, www.statistics.gov.uk, Guernsey Facts and Figures 2010, Isle of Man 2010 Digest of Economic and Social Statistics, www.highland.gov.uk, Orkney Economic Review 2010, Shetland Statistics 2009, www.cne-siar.gov.uk 


\section{B. Canavan}

\section{Literature Review}

\section{Depopulation in Small Islands}

Depopulation in small islands can be traced to several challenges facing their inhabitants, linked closely to their small size and peripherality: their contribution is seen to undermine economic development options (Arremberri, 2005). Andriotis (2005: 115) summarizes the limiting consequences of peripherality:

"By their very nature islands face a number of inherent disadvantages. They are small in size with declining populations; they suffer from isolation, peripherality, external dependency and diseconomies of scale; they are rural in character; and they have a scarcity of resources, meaning mainly that their alternatives for industrialisation and self-sustaining growth are limited."

Meanwhile, Keane (1992: 407) further details the link with population loss:

"The problem of sustaining population on small coastal islands is a difficult one. The difficulties are created by the limited resource base and consequently limited employment opportunities, by the restrictions which size can place on the provision of services, and by the problems of access to markets and to the mainland."

The dearth of economic opportunities on small islands is pinpointed as a motivation for emigration, particularly of young people who seek better employment and earning prospects abroad (Spilanis \& Vayanni, 2004). This is exemplified within the Highlands and Islands of Scotland by Wilkinson (1987), Laws (1995) and Damer (2000), who all highlight the loss of residents to economically more productive and diversified areas.

Poor educational options at home are a further motivator to leave small islands, again for young residents in particular (Marjavaara, 2009). Educational opportunities on many small islands are limited; in recognition of this, the Isle of Man government has developed some local degrees, teacher training, and police training to try and combat this. However, Smith (2003) points out that people do not only seek knowledge, training and certification; they may desire to go beyond their local community for wider experiences. Other drivers of emigration include: the lack of perceived excitement compared to the mainland (Andriotis, 2005); traditional and arduous, often subsistence lifestyles, not appealing to younger generations (Royle, 2003); and house prices being too high and simply unaffordable (Laws 1995).

Out-migration within small islands is a significant and serious threat. Royle $(2003,2008)$ describes the outflow of residents from the Irish islands, many of which have been permanently abandoned leading to a loss of their unique cultures, way of life, and local knowledge. Péron (2004) highlights population trends which have seen the French Atlantic Islands shed around half of their populations over the 20th century. In the British and Irish islands, downward trends have been equally stark. For instance; in 1841, 211 islands off the coasts of Ireland, held a population of 38,138 ; in 1999, only 66 islands were inhabited by just 9,700 (Berry, 2009). 
Whilst in most of the British islands populations are now stable or growing (see Figure 3), this can be a fragile situation; both Royle (2003) and Péron (2004) have noted this has only been the case for a short recent period in history, and is often not the case for the smallest islands which continue to lose inhabitants. Moreover, population figures can be boosted artificially by the recording of summer residents; though it must be said that even temporary residents are better than full abandonment, and may help to support permanent residents. Indeed, Royle (2008) concedes this to be the case on islands off the coast of Ireland: those recording more stable populations have also tended to attract summer residents.

Figure 3: Population change rates in selected British Islands, 2001-2009.

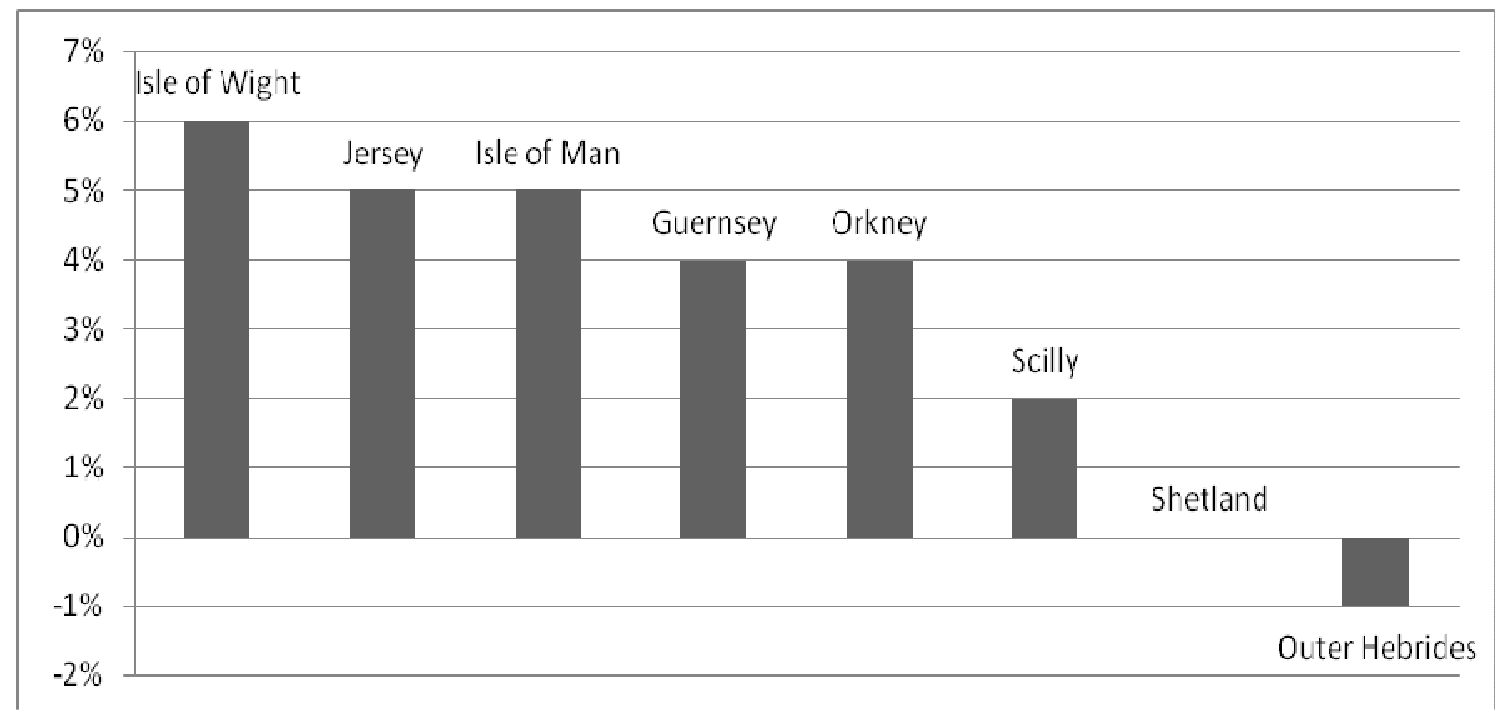

Sources: www.statistics.gov.uk, Jersey in Figures 2010, Isle of Man 2010 Digest of Economic and Social Statistics, Guernsey Facts and Figures 2010, Orkney Economic Review 2010, Shetland Statistics 2009, www.cne-siar.gov.uk

* Isle of Man up to 2006, Scilly and Wight up to 2007, Shetland up to 2008.

\section{Economic Development and Out-migration}

Economic development is vital to sustaining island populations. It is needed to support community facilities, which are often proportionately more expensive to provide due to limited local resources requiring imports and low per head usage (Portrait of the Islands 1994). Economic development brings vital income to pay for necessary imports (Ayres, 2000), and provides essential employment and income opportunities locally, so that residents may remain, émigrés return, or outsiders be attracted to relocate. Andriotis (2005) describes how tourism in the Greek islands has halted emigration and encouraged the return of former inhabitants, keen to exploit the resulting financial opportunities. Such inmigration is vital to sustaining communities economically and demographically, enabling maintenance of community facilities (Baldacchino, 2006). Moreover, the boost to social life of new inhabitants is noted by Damer (2000); Duffield \& Long (1981) explain how these newcomers support a range of entertainment facilities, whilst Marjavaara (2009) 


\section{B. Canavan}

highlights how having more people around provides greater options for social interaction, mutual learning and cultural exchange, all of which can help combat the sense of isolation which small island life can create. Finally, the attention and interest of newcomers can stimulate self-worth, civic pride and a sense of identity in a place (Smith, 2003); this may encourage people to remain somewhere they feel proud of.

Nonetheless, the capacity of islands to deal with in-migrants may be limited, particularly regarding competition for housing stock. Any inward migration inevitably increases demand for limited island housing, resulting in inflation (Latimer, 1985). Moreover, inward migrants often have greater financial resources than island dwellers, meaning they can outcompete indigenous residents, especially those with limited resources including the young, who may subsequently be excluded from home ownership (Marjavaara, 2007). Additionally the residents of small islands tend to be traditional, somewhat set in their ways, and to have their own unique customs and values (Berry, 2009). Resentments may be caused where locals feel that outsiders do not respect these, and enforce or expect unwanted, too much, or too rapid change. Rising house prices are a visible symbol of change, and can act as a lightning conductor for resident resentments; as Smith (1989) points out, negatives are often loaded onto tourists and migrants out of proportion to their impacts, due to their visibility, a lack of adequate local knowledge, and in some cases political cynicism which may use as a scapegoat for wider, more deeply rooted problems.

Nevertheless, a degree of inward migration and second home tourism can bring host communities various benefits. Laws (1995), for instance, concludes that criticisms of second home owners are misplaced, as they generate significant economic input in rural island economies otherwise unable to support many full time residents. Similarly, Strapp (1989) believes that the benefits to facilities and employment of second home owners help to maintain viable communities which would otherwise be able to support fewer full time residents. Even Royle (2008), critical of small islands selling out and losing their identity in their fight to attract outsiders, concedes that those islands which have done so have a more promising future, while those that haven't continue to slide towards abandonment.

Second home purchasers may cause problems in areas with low population densities, where incomers are likely to be highly visible, and felt to be imposing change by virtue of this visibility. Also in locations which are experiencing wider changes, such as falling employment levels, or a decline in the use of the native language, these create or foment underlying tensions amongst residents which may then be blamed on incomers. Furthermore, tourism can inflate property prices, driven by returning or new workers in the industry, and second home purchasers or retirees, who compete for local property according to Beeton (2005). Damer (2000) likewise identifies two key sources of property price inflation beyond the means of locals: scenic and economic migrants; typified as those retiring, relocating with children to, or purchasing second homes for holidays, because of areas attractiveness. For example, in the Scottish Highlands, Duffield \& Long (1981: 420) identify tensions with incomers, in large part because: "their presence creates competition for property, causing prices to rise beyond the reach of many local residents."

Much of the literature suggests that the impact of migrants on host communities is mixed. For instance, Strapp (1988) finds that second home owners make significant financial inputs to isolated communities, but they also alter the social make-up and atmosphere of a place. Discussing Orkney, Forsythe (1982) argues that the local way of life was being overwhelmed by a more homogenized ethnic, religious and cultural influx. In Arran, 
Damer (2000) portrays the antipathy of residents towards second home owners seen as diluting local culture, and Van Ginkel (1995) finds likewise in Texel. Smith (2003) strikes a balanced tone when she argues that cultural interaction and change has many mutual benefits, remaining the same is not necessarily a virtue, whilst the extent of change is often overstated.

There are links between inward migration for such purposes and 'gentrification' of a place; described by Jackson (2006) in her case study of Bruny Island, Australia, as the gradual replacement, upgrading and addition of more expensive properties, particularly in coastal areas. She finds signs of displacement of poorer residents and concerns over future generations being able to afford to live locally. Similarly Clark et al. (2007) describe conflicts for the limited space on islands between permanent residents and summer visitors in Sweden's Gothenburg archipelago.

At the same time, a distinction has to be made between such migrants, who are likely to take an active part in the local economy and social life, and migrants purchasing property for investment or tax avoidance purposes, whose impacts are more negative, in that they spend little time in the community (Hampton \& Christensen, 2007). They are also likely to purchase cheaper property intended for conversion, or replacement into more expensive housing, thus pitching the market towards the luxury end (Marcuse, 1985). Moreover, large scale investors and developers can be responsible for new building developments whose impacts may be out of keeping with local architecture and opinion; Royle (2008), for example, attacks the ugly modern housing built all over Ireland during the property boom, scarring local landscapes and not fitting well with local needs or tastes. Second home owners operating individually, and often with an enthusiasm for restoring older properties, may instead help to maintain local landscapes. On the Isle of Man moreover, although figures are not available, the latter group would appear to be much more significant in terms of home ownership, and are viewed with hostility, whereas holiday home owners are largely welcomed.

\section{Methodology}

Single and group interviews were conducted in May-July 2010, by the author. A nonrepresentative sample of young Isle of Man inhabitants and émigrés was interviewed. Most of these had attained tertiary education qualifications at UK institutions. It was considered important to speak with highly qualified youth who may be assumed to be valuable members of the island's economic future as skilled employees, and have been educated at considerable taxpayer expense: local government heavily subsidizes university education. Such well qualified persons are attractive to employers, and thus have a variety of employment options, meaning they can be more selective about employment opportunities, on or off-island. They might also be expected to obtain good jobs, wages, and be representative of a middle class segment of society, and as such would be expected to own their own property in the future.

The subjects interviewed are largely typical of educated youth (Yin, 2003): they were between 19 and 30 years of age; had been to a variety of higher education establishments, including universities (ranging greatly in academic ranking), agricultural colleges, medical schools, business schools and further education colleges; studying diverse subjects; wielding a range of qualifications, both academic and vocational; and now pursuing a variety of careers or further education opportunities on or off-island. Interviewees 


\section{B. Canavan}

identified from personal knowledge, network recommendations, and databases such as the Isle of Man graduates website (www.manx-graduates.co.im). Networking and snowball sampling were used to access and recruit additional individuals.

A total of 24 interviews were conducted, lasting between 25 and 70 minutes, with an average length of 45 minutes. All interviews were tape recorded, and transcribed the same or following day. Most interviews were conducted on-island at locations chosen by respondents, usually their place of residence; though a small number of interviews with émigrés were conducted off-island. In-depth interviewing was chosen as the key tool for gaining insights into participants' thoughts, opinions and emotions and for exploring loosely defined, highly subjective topics (Huberman \& Miles, 2002). Johnson et al. (2006) discuss how this type of qualitative research captures the meanings and interpretations actors subjectively ascribe to phenomena, whilst Miner and Mezias (1996) argue that such a technique allows one to look at and interpret results within a wider social specific context; a particularly important consideration in appreciating motivations to stay or leave the island. A discussion guide (Appendix A) designed to stimulate conversation about the Isle of Man, local property prices, and reasons for staying or leaving, was used. Questions sought to explore why respondents had chosen either to return to the Isle of Man after graduation, or to stay abroad; while those that had stayed on-island were prompted about their assessments and future prospects of staying on the Isle of Man. This template was loosely adhered to, since many conversations were free flowing and required little researcher prompting as subjects were happy to talk at length and in detail on the subject.

\section{Findings}

\section{Reasons for Staying or Leaving the Isle of Man}

Interviews explored the reasons young people stayed, left or were considering leaving the Isle of Man. It became apparent that employment opportunities were the main motivation to leave for those who had done so. Young émigrés believed they experienced wider and better employment opportunities in the UK:

There is not the range of jobs on the Isle of Man... here I have potential to go into all sorts of areas with my degree; am not just limited to finance. (Émigré, 24)

You couldn't do what I'm doing on the island. (Émigré, 23)

Those who remained on island worried that they were making a decision that would limit their future earnings potential and thus felt they should move and pursue better job prospects off-island. Despite affection for the island amongst almost all interviewees, for many the lure of greater opportunities off-island was more influential:

It is my home but work opportunities would be greater... I love it here but if my job isn't going to go anywhere and I can't see it really... (Resident, 24)

Furthermore, island jobs were frequently characterized as hard, dull and with limited future prospects, whilst friends or colleagues who had relocated to the UK or other foreign 
countries were seen as better off, prompting residents to consider leaving, and justifying why émigrés had done:

It's so boring... six months and have done it all then that's it for four, five years until I might get promoted to another office. (Resident, 22)

Some of the lads from my course... now they are in Australia earning 50-60 grand and you don't really need all that or anything... When these firms were recruiting I didn't want to leave but now I think I should have but it's too late; they want you straight from uni. (Resident, 23 - subsequently emigrated)

Nevertheless, some respondents did describe how they enjoyed their job and that the island offered a good range of opportunities, perhaps better than elsewhere in light of job cuts in the UK, less competition for jobs or promotions, safe working environment and availability of training. Perhaps what was most appreciated was a suitable work-life balance and being able to work and live in such a beautiful location:

Well, yes it is easy to moan isn't it, but really it is like I say 'Isle of Man problems at work are nothing compared to UK'. Like commuting; here, a delay of five minutes not five hours is bad and you have time to go walk the dog in the evening and just have a life. (Resident, 30)

Social factors were also cited by both residents and émigrés as influencing a desire to leave the island, though particularly by those who had not returned following university. Émigrés mentioned at some length the inadequate entertainment facilities and limited social pool available, even that the calibre of that pool was not suitable to them. One respondent highlighted a limited alternative scene on island, referring to a self interest in organic, environmentally aware activism. Many émigrés described how dull and uninspiring the island seems when they return to visit, and that they do not miss it:

The Island does not provide the social environment that I want as a recent graduate and young professional. (Émigré, 22)

I find the island very small... I get bored after a couple of days back home. (Émigré, 23)

It (leaving) is the best decision I have made... it is the people you meet, I always felt out of place (on the island), but here I can be me... it is normal what I am, you don't have people judging you all the time, and that feels great. (Émigré, 22)

Various island residents revealed that they heard such complaints quite often; some not only disagreed, but also found them offensive, fearing that they might put tourists off visiting the island, and belittling their decision to stay:

So he says, and this used to be an old friend of mine, lives across (meaning in England) now, say he only comes back because of visiting parents, that it is boring and he would not otherwise come. I just think '**** you'; what is so special about where you live or what you think? It isn't even like he goes to the opera every night or anything. Maybe you can make that choice but don't have to belittle others. (Resident, 23) 


\section{B. Canavan}

A further point made by respondents, both residents and émigrés, was that the island was more suited to families and older people. Various facilities intended for younger people had been replaced by others catering for seniors; a perception also highlighted by Marjavaara (2007). This was linked to the discussion about lack of facilities, principally evening entertainment or drinking venues, as well as networking opportunities with similar people:

All the venues for live bands have been closed down and turned into old people's flats. (Émigré, 23)

Well, now you haven't even got Nightlife (a former nightclub) have you; there is nowhere to go outside of Douglas [the capital]. Ramsey is dead now on a Friday night. (Émigré, 23)

I want to leave because I'm not old or a parent. (Resident, 19)

There are too many old people and I hate old people! (Resident, 21)

\section{Property Prices}

Whilst émigrés did not explicitly draw links between desire to leave and property values, it is likely that they are connected. For instance, the loss of facilities mentioned is partly driven by commercial venues being converted into residential developments. One respondent also explicitly described the affordable value of UK property prices compared to those on the island. When prompted, others did express an opinion that island house prices were too high, making it difficult for young people to settle down or move out of poor quality rentals. Some respondents were relieved not to have to be a part of this, though they did not draw links with their own decision to leave:

I think there are greater opportunities here, that is the main thing. But yeah, to not be in that situation (living at home) is a good thing. (Émigré, 23)

For those choosing to remain on the island however, property prices emerged quickly as a key issue. It became apparent through conversations that high house prices were a cause of distress for this group. Many were worried they would be unable to remain on island and felt obliged to do the sensible thing by moving away. Respondents considered it unlikely they would ever be able to afford a house of their own leading to the situation:

I can live with mum and dad until I'm thirty and never have sex until then, or can rent a **** room and never have any savings. Yay. This is not exactly what I went through uni for to come back to. (Resident, 23)

Faced with remaining in the family home or expensive rented accommodation in the longterm, many participants were considering emigrating abroad despite it not being their desire to do so. One interviewee was thinking of applying for jobs in Australia because of the higher earnings potential in his field; but he was loathe to leave family and friends behind. His comments illustrated the importance of wages and employment in considering emigration, yet he was also impressed by how cheap Australian property was, and felt 
forced to apply because of the "unacceptable living arrangements" at home, highlighting how property exclusion can lead to eventual displacement: he subsequently did emigrate. Other interviewees remarked on what attractive value UK or Australian property was, compared to that on the island:

... .pool, fields, four bedrooms, massive bathroom; all on a teacher's salary and she doesn't work either. (Resident, 22)

It's ridiculous, when I was in England can see really nice houses, four bedroom houses, garage, garden, that are 200 thousand [sterling]. Here that wouldn't even buy a two bed bungalow. (Resident, 22)

I know it's horrible, I don't really want to live there (UK), they're not nice places really, not a nice country, but if you get a big house rather than a flat; well how much living do you actually do in that compared to the outside? I don't know. (Resident, 23)

A detailed knowledge of the local property market, and a passion for property, were expressed by many interviewees, who described their ideal house, location and architectural style in detail. Many were able to name houses currently for sale, how much they were priced an how expensive this was for the number of bedrooms, size of garden and so on. Such comments were usually made with an air of resignation to the fact that the property market is ridiculously over-priced and shows no signs of easing. Those asked did not believe that a property price downturn, as has happened in parts of the UK, would happen, though they explicitly hoped it would. Respondents wishing to remain on the island appeared to have low expectations of owning anything beyond a modest property in their lifetime, and saw few signs that this would change other than if they moved away. This was expressed regardless of profession or level of education, suggesting house prices are so removed from earnings, that ownership seems unrealistic even for well paid jobs, and expectations are low.

\section{Pressure to Have One's Own Home}

Young residents felt pressure to move out of living with their parents, feeling failures or babyish if they had not:

It's not exactly what you picture yourself doing at nearly thirty is it... know now not going to be a film-star or anything, but still living at home is just pathetic. (Resident, 29)

This compounded already undesirable living arrangements. Interviewees expressed some embarrassment about the issue as they felt it diminished and infantilized them, keeping them in a state of limbo between being children and responsible working adults. Living at home thus was also stressful and limiting:

I just wish, sometimes I want to kill them always going on at me... can't just have friends round... they're always there! (Resident, 24) 


\section{B. Canavan}

However, positive comments about living at home with parents were also made:

I'm just really comfortable where I am, I know I should not just get stuck in, but I have everything I need, we all get on really well. (Resident, 23)

External expectations, which make people feel they should be moving out of home to be independent and fit in with wider social norms, were acknowledged by all respondents still living at home. Several interviewees mentioned negative comments by outsiders making them feel inadequate and under pressure to move out:

... so he says 'how old are you' 22, 'and you're still living with your parents; that's a bit pathetic isn't it' which I thought '**** you' especially as I'd just lied about my age. (Resident, 23)

She asked me my age, and obviously it being my birthday I have to tell her and I say '24' and her face just falls like she couldn't believe how old I was and it's not a nice thing. Can tell she is shocked that I am so old and haven't even got a proper job, or a wife, children and so on. I now actually lie to people about my age because I can't stand what they're thinking. It's OK if they think you're still a student. (Resident, 24)

I'm actually quite happy where I am, but I know people are starting to talk, say I'm bit weird and stuff. I think my mum thinks I'm a lesbian! (Resident, 23)

Respondents felt caught in a trap; under pressure to move out and be independent, but lacking financial and emotional means to do this, because living at home restricted opportunities; and yet, home ownership was such a far-off and unrealistic goal:

My dad is always telling me; 'by your age I had a wife and two kids' and I think; 'yeah but you also had a house and good job': It's not like I don't want to... I can't see what I'm going to do actually. (Resident, 21)

\section{Consequences of Property Exclusion}

The previous quote reflected a conversation thread amongst some respondents who felt unable to fulfil personal ambitions because of living arrangements. This went beyond feeling immature and inadequate compared to peers and unable to act freely, to deeper family planning issues. Both those still at home and those living in rented, often small, accommodation felt that they had to put off having children because it would not be suitable to bring them up without a home:

I don't care; I just want a house so I can have children! (Resident, 23)

... that is awful, you have to start so early and we are actually at the age when we should be starting already, but it is this... feel like a child and yeah not having my own place is part of that, definitely, you kind of aren't ready... or in a place able to. But biologically it might be too late. (Resident, 23) 
A further consequence of property exclusion was disenchantment with both occupational and personal lives because tangible benefits of one's efforts could not be achieved:

Still living with my parents... How long will it take me to even save the deposit? So I'm just going to work for six months and then go travelling again; it's all I can stand. (Resident, 21)

Yeah, it is scary; you know that this is your life now for the next forty, fifty years, like just work every day, occasional holidays... It wouldn't be so bad if had something to go back for... like family to support and support you, not just a flatshare and pot noodle. (Resident, 29)

Even those on the property ladder were downcast analysing their situation:

... got a 25 year loan, not 30; that way I'm 55 not 60 when it's paid off and there's time to put money aside to do something else. But that is just for a two bedroom flat; my life's work. Literally. (Resident, 30)

In contrast, though most had not yet purchased any property, émigrés did not appear concerned by this. Rather they were excited about living abroad and concentrating on career development. This may be due to a lower desire to start families, a more ambitious disposition, or the freedom from worrying about being able to afford a property in future, whilst at present enjoying affordable rents and a higher propensity to save:

Yeah I guess, I mean obviously I will (buy a property), but I mean I have got like a lot of stuff on with work and... rent here is really reasonable. (Émigré, 23)

I will buy a property when the time is right. At the moment I just don't want the responsibility. (Émigré, 22)

\section{Generated Anger}

Considerable anger at high house prices emerged from interviews amongst residents. Generally, respondents were very cynical about the housing market on the Isle of Man. Natural and architectural environments were seen as threatened. Most talked about landscapes that had been damaged or historic buildings lost:

Why do we let them come and spoil our old houses? They pulled down all those ones by the harbour, it's just to make a bit of money and sod the rest of us who live here. (Resident, 30)

If they [developers] had their way, they would turn the whole island into one big housing estate... They have done it to Jersey, it is (now) a horrible place... and they are letting it happen here. (Resident, 21) 


\section{B. Canavan}

... will turn the island into a ****** ghetto, a playground for the rich who are only there half the year. (Émigré, 23)

Interviewees believed that the property market did not much benefit the majority of islanders, especially younger and older residents. Instead, foreign investors and developers were thought to reap huge profits. Such people were seen to make little contribution to island society, merely being resident to speculate, and then to leave when they had made enough money:

What do we actually get out of it? It is the super rich hiding their money and English builders over here because they can charge double what they do in the UK who benefit. (Resident, 21)

The island has prostituted itself to a few rich old white men at the expense of its future, and dignity. (Resident, 24)

Non-English speaking immigrants were unpopular amongst a significant minority of residents, due to perceptions they could enjoy children and housing with state financial support; something many thought denied to them.

Can't stand it; every time I look in the births, [the newborn] has a Polish surname. Why do we let them in in the first place?... why let in their women who then just breed from minute they get here and we have to pay for it all? It's ridiculous. (Resident, 23)

If you look at the numbers of them (foreigners) then there are too many. If they all just ****** off we would have much lower rents and competition for houses. (Resident, 30)

Such angry, racist views were surprisingly forthcoming and freely expressed, in spite of being politically incorrect. There is apparently a lot of anger being stirred up by house prices and consequences of exclusion from property, and the family opportunities and selfimage which are conferred by property ownership. Attacking immigrants appears to be an easy outlet for such anger. The irony is that these immigrants are often economically marginal persons who probably have the least influence over property prices.

\section{Discussion}

The research findings support the view that lack of employment, education and social opportunities are the principal reasons why young émigrés have left the Isle of Man, and drive others to consider doing so.

However, the findings also suggest that property inflation exerts significant pressure on young inhabitants who choose to remain on island long-term, generating considerable tension and anger at exclusion from property ownership. Delaying starting a family causes resentment among young island inhabitants, some of which appears to be misplaced onto 
visible, easy targets such as non-English speaking immigrants. Furthermore, it is likely that property exclusion would rapidly become property displacement, if young residents were not able to remain living with their parents. It may be that slightly older residents as well as those in their late twenties and early thirties, experience a stronger displacement effect, as it becomes more difficult for them to continue living at home. More research is needed to investigate this.

As in the case documented Forsyth (1982), interviewees were concerned about the negative consequences associated with property price inflation, such as environmental damage, and the influx of outsiders altering and not always appreciating local culture. The growing sense of displacement amongst original residents, as traditional community facilities are replaced by different ones, serving the demands of new residents, is described as "replacement is displacement" by Slater $(2008,213)$. Such a situation appears to be unfolding on the Isle of Man, and it is this, rather than any innate hostility to incomers per se, which triggers unreceptive attitudes. Poor quality developments damaging the landscape, and the demolition of historic buildings causes the most acute concerns; the link to property development is clear in these cases. Hostility to speculation, seen as detrimental to the wider community and the natural environment, was expressed, and many builders are viewed as unscrupulous, from off-island, visiting temporarily, just to make money and put profit before community welfare. Property developers are unpopular amongst young residents, and viewed as symbolic for all that is going wrong in terms of unsustainable development, benefitting a narrow pool of people, whilst altering local character.

In line with other research, these findings highlight a threat to community continuity, happiness, stability, and in the long-term, sustainability on the Isle of Man. If not acknowledged and countered by policy makers, such anger may lead to rising racial tensions (as people look for someone to blame), or to the exodus of skilled young residents. It is clear that measures have to be taken to control excessive property inflation, if less wealthy members of the community, including many young residents, are not to feel excluded. Current measures, such as mortgage assistance for first time buyers, are welcome; but with even the cheapest property on the Isle of Man; a one bedroom apartment, costing nearly $£ 100,000$, the time required to build a deposit is considerable.

Efforts need to be taken to slow the increase in Manx property values. There are a range of options available for local government to achieve this, such as a tax on second homes and non-permanent addresses used by generally wealthy migrants, investors, or tax avoiders. At present the only property taxes on the island are council rates. The absence of capital gains tax does nothing to deter speculators from buying, upgrading and selling property or developing land for large profits none of which go back into state coffers. What is more, such property development often concerns the upgrade of relatively cheaper property bought for upgrade, thus lessening the amount of low cost property available overall. In addition, no inheritance tax is charged on the Isle of Man, meaning that there is no discouragement from accumulating property. The Isle of Man tax policy, which benefits the island population in attracting finance companies which are major employers, but disadvantages many by doing little to dampen property inflation or to spread the benefits of those who gain from the market, needs critical and serious analysis. Marcuse (1985) outlines a variety of policies governments may use to control property inflation, with taxes being a key tool, including anti speculation and luxury housing taxes. A second home tax, or introducing capital gains or inheritance taxes, would achieve this. A second home tax might reduce demand for second homes by adding to the cost of ownership, while capital 


\section{B. Canavan}

gains tax would allow the Isle of Man government to benefit from developer profiteering, and may control the growth of that industry. The key target would be speculators banking property for future development, and tax migrants using an island address for financial purposes, rather than second home owners. It is clear that second home owners make an important contribution to island' economies, and their relatively small scale is unlikely to be a major cause of inflation. Rather than discourage such a group, a modest second home tax might generate small but significant income for targeted use, such as to extend the house purchase assistance scheme, or build more low income housing. A final tax policy could be the introduction of tax breaks for multiple occupancy households, encouraging house-sharing opposed to single occupancy (common in an island with a large elderly population), and perhaps also removing some of the stigma of living with families past the age of 21 .

A number of other measures implemented in similar locations could be considered. The reserved housing policy of Jersey, which gives priority to local residents for some property, is somewhat discredited by the extreme property prices on the island, and local anger at exclusion (Hampton \& Christensen, 2007). Anti displacement zoning, with provision of decent, secure and affordable housing (Marcuse, 1985), is another strategy, and exists to an extent on the Isle of Man with developers having to allocate a proportion of new-build properties as affordable housing, though it is limited by the spatial constraints of a small island, which make new developments generally small scale.

As Marcuse (1985) highlights, the most significant contribution that can be made to curbing displacement is reducing the polarization of the economy, with control of speculative actions. Taxes would be a powerful way for rebalancing the Isle of Man economy which, in its dependence on international finance and obsession with attracting wealthy individuals as a symbol of success, is a most polarized and unregulated economy. Yet, a perceived lack of alternatives for economic development, and a past with long periods of economic stagnation and population decline, means that local policy makers are loath to take such measures. Finance is a highly internationalized and mobile industry, which often threatens to leave a jurisdiction when regulations are proposed. The Isle of Man government is in a difficult position, nevertheless, at the very minimum, politicians may be reminded to rethink policies likely to stoke anger amongst the public because they are seen to benefit wealthy foreign investors; for example, the recent announcement to allow 'high net worth individuals' to build property on green-belt land with little planning requirements (Isle of Man Newspapers, 2010). Such a proposal not only generates questions of a two-tier system with the rich able to do as they please, but also emphasizes the encouragement of outside investment in a limited and overheated property market.

A final comment is that the island would benefit from more accurate data about the number of second homes on the island, and extent of social and economic inequality, in order that progress could be tracked and measures taken. Gini-coefficients are not available for the Isle of Man, however, the government does collect and publish many informative domestic statistics; some basic changes to these would signify a stronger commitment to issues of inequality. The lack of such statistics suggests a lack of appreciation by the Isle of Man government of the problems of rising inequality which may be linked to property inflation. This may explain why there is so little debate on the topic locally, and why so many interviewees felt frustrated, powerless and not optimistic that things would change for the better. 


\section{Conclusion}

Economic success generating employment possibilities in small islands is needed to counter the depopulation trends such that communities face. However, that success can drive property price inflation, which in turn displaces local inhabitants, particularly the young, and may hasten both a sense of loss of community and population ageing. Marcuse (1985) describes this as a displacement that can occur at both ends of the spectrum of spatial change: abandon and gentrification. With abandon such a threat to small island communities, the sacrifice of some young people who feel excluded, may be seen as an a small price to pay in exchange for maintaining a vibrant economy. One must also question the purpose of economic growth per se in such close-knit communities, if it largely benefits outsiders, and very wealthy ones at that, to the disadvantage of many local residents.

The potential of property inflation to seriously destabilize social sustainability in small communities is apparent from the Isle of Man case. There, many young inhabitants come across as demoralized about their future on the island, due to exclusion from property ownership. A sense of exclusion from property ownership also connects with a sense of exclusion from images of success in the eyes of oneself and others, and may be a precursor to property displacement as people feel compelled to move away in order to meet social, financial and family planning goals. Overall, it is clear that high property values risk pushing out young residents from the Isle of Man. Considerable distress is caused by present exclusion and fear of future displacement, even amongst highly educated and skilled young residents in demand from local employers.

Without a detailed political solution to address the issue, youth emigration, loss of social continuity and public disquiet are all likely to grow, and ugly manifestations such as xenophobia may increase. The issue cannot continue to be ignored; as Slater (2006) details, the apathy of political leaders towards negative aspects of gentrification, and their lack of discussion of negative consequences, including an affordable housing crisis and community upheavals, need to be combated. This article hopes to draw attention to the negative consequences of property price inflation in a case study with an interesting mix of considerations. When even middle class community members feel that home ownership is a distant, perhaps unrealistic ambition, then the need for a political appreciation of, and focus on, property exclusion is clear.

With small islands caught between the threat of depopulation and competition for limited resources, there may be little room for manoeuvre, and with the latter a less frightening prospect, measures to address displacement should be taken carefully. But that is not to say they should not be taken at all. The risk of inaction over the long term is likely to be worse.

\section{References}

Andriotis, K. (2005) 'Seasonality in Crete: A Problem or a Way of Life?', Tourism Economics, Vol. 11, No. 2, pp. 207-224.

Aramberri, J. (2005) 'How Global is Tourism?' in J. Aramberri \& R.W. Butler (eds.) Tourism Development: Issues for a Vulnerable Industry, Clevedon, Channel View, pp. 127152. 


\section{B. Canavan}

Ayres, R. (2000) 'Tourism as a Passport to Modernization in Small Island States: Reflections on Cyprus', International Journal of Social Economics, Vol. 27, No. 2, pp. 114-133.

Baldacchino, G. (2006) 'Innovative Development Strategies from Non-Sovereign Jurisdictions? A Global Review of Economic Policy and Governance Practices', World Development, Vol. 34, No. 5, pp. 852-867.

BBC (1996) Close Up: Storm in a Haven. Broadcast on British Broadcasting Corporation-2 (13 November).

Beeton, S. (2005) Film Induced Tourism, Clevedon, Channel View.

Berry, R. J. (2009) Islands, New York, Harper Collins.

Bramwell, B. (2004) 'Mass Tourism, Diversification and Sustainability in Southern Europe's Coastal Regions' in B. Bramwell (ed.) Coastal Mass Tourism Diversification and Sustainable Development in Southern Europe, Clevedon, Channel View, pp. 1-31.

Briassoulis, H. (2004) 'Crete: Endowed by Nature, Privileged by Geography, Threatened by Tourism?' in B. Bramwell (ed.) Coastal Mass Tourism Diversification and Sustainable Development in Southern Europe, Clevedon, Channel View, pp. 48-67.

Buckley, R. (2002) 'Surf Tourism and Sustainable Development in Indo-Pacific Islands', Journal of Sustainable Tourism, Vol. 10, No. 5, pp. 405-424.

Clark, E., Johnson, K., Lindholm, A. \& Malmberg, G. (2007) 'Gentrification and Space Wars' in G. Baldacchino (ed.) A World of Islands: An Island Studies Reader, Charlottetown, Canada \& Luqa, Malta, Institute of Island Studies, University of Prince Edward Island \& Agenda Academic, pp. 483-512.

Cooper, C. (1995) 'Strategic Planning for Sustainable Tourism: The Case of the Offshore Islands of the UK', Journal of Sustainable Tourism, Vol. 10, No. 5, pp. 363-383.

Damer, S. (2000) 'Scotland in Miniature? Second Homes on Arran', Scottish Affairs, No. 31, pp. 2-18.

Duffield, B. \& Long, J. (1981) 'Tourism in the Highlands and Islands of Scotland: Rewards and Conflicts', Annals of Tourism Research, Vol. 8, No. 3, pp. 403-431.

Forsythe, D. (1982) Urban-rural Migration, Change and Conflict in an Orkney Island Community, London, Social Science Research Council.

Gephart, R. (2004) 'Qualitative Research and the Academy of Management Journal', Academy of Management Journal, Vol. 47, No. 4, pp. 454-462.

Guernsey Facts and Figures (2010)

www.guernseyfinance.com/literature/guernsey-facts-figures-2008. 
Hall, M., Muller, K. \& Saarinen, J. (2009) Nordic Tourism: Issues and Cases, Clevedon, Channel View.

Hampton, M. \& Christensen, J. (2007) 'Competing Industries in Islands: A New Tourism Approach’, Annals of Tourism Research, Vol. 34, No. 4, pp. 998-1020.

Huberman, M. \& Miles, M. (2002) The Qualitative Researchers Companion, London, Sage.

Isle of Man Government Digest of Economic and Social Statistics (2010) www.gov.im/treasury/economic/data/population.xml.

Isle of Man Newspapers (2010) 'Tynwald backs plans to create homes for the rich', http://www.iomtoday.co.im/news/isle-of-man-

news/tynwald backs plan to create homes_for_rich_1_1747296

Isle of Wight Demographic Data (2010) www.neighbourhood.statistics.gov.uk/dissemination/LeadKeyFigures.do? $\mathrm{a}=3 \& \mathrm{~b}=276857$

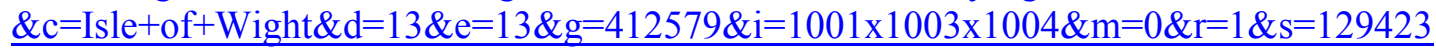
$\underline{5728262 \& \mathrm{enc}=1}$.

Jackson, R. (2006) 'Bruny on the Brink: Governance, Gentrification and Tourism on an Australian Island', Island Studies Journal, Vol. 1, No. 2, pp. 201-222.

Jersey in Figures (2010) http://www.gov.je/News/2011/Pages/JerseyFigures.aspx

Johnson, R., Buehring, A., Cassell, C. \& Symon, G. (2006) 'Evaluating Qualitative Management Research: Towards a Contingent Criteriology', International Journal of Management Reviews, Vol. 8, No 3, pp. 131-156.

Jura Community Survey (2010) www.juradevelopment.co.uk/images/2010/10/Jura-Community-Survey-30-09-1011.pdf.

Keane, M. (1992) 'Case Study: Strategic Management of Island Tourism - The Case of the Aran Islands’, Tourism Management, Vol. 13, No 4, pp. 406-414.

Latimer, H. (1985) 'Developing Island Economies: Tourism versus Agriculture', Tourism Management, Vol. 6, No. 1, pp. 32-42.

Laws, E. (1995) Tourist Destination Management: Issues, Analysis and Policies, London, Routledge.

Marcuse, P. (1985) 'To Control Gentrification: Anti-displacement Zoning and Planning for Stable Residential Districts', New York University Review of Law and Social Change, Vol. 13, pp. 931-945.

Marjavaara, R. (2007) 'Route to Destruction? Second Home Tourism in Small Island Communities', Island Studies Journal, Vol. 2, No. 1, pp. 27-46. 


\section{B. Canavan}

Marjavaara, R. (2009) 'Second Home Tourism and Displacement in the Stockholm Archipelago', in M. Hall, K., Muller \& J. Saarinen (eds.) Nordic Tourism: Issues and Cases, Clevedon, Channel View, pp. 192-201.

Milner, A. \& Mezias, S. (1996) 'Ugly Duckling no more: Pasts and Futures of Organizational Learning Research', Organization Science, Vol. 7, No. 1, pp. 88-99.

Orkney Economic Review (2010) www.orkney.gov.uk/Service-Directory/E/Economic-Information.htm.

Péron, F. (2004) 'The Contemporary Lure of the Island', Tijdschrift voor Economische en Sociale Geografie, Vol. 95, No. 3, pp. 326-339.

Royle, S.A. (2003) 'Exploitation and Celebration of the Heritage of the Irish Islands', Irish Geography, Vol. 36, No. 1, pp. 23-31.

Royle, S.A. (2008) 'From Marginality to Resurgence: The Case of the Irish Islands', Shima: The International Journal of Research into Island Cultures, Vol. 2, No. 2, pp. 4255.

Scilly Isles Demographic Data, www.statistics.gov.uk/census2001/profiles/15uh.asp.

Sharpley, R. (2003). 'Tourism, Modernization and Development on the Island of Cyprus: Challenges and Policy Responses', Journal of Sustainable Tourism, Vol. 11, No. 2, pp. 246-265.

Shetland in Statistics (2009) www.shetland.gov.uk/documents/SinStatsBinder1.pdf.

Slater, T. (2006) 'The Eviction of Critical Perspectives in Gentrification Research', International Journal of Urban and Regional Research, Vol. 30, No. 4, pp. 737-757.

Slater, T. (2008) 'A Literal Necessity to be re-placed: A Rejoinder to the Gentrification Debate', International Journal of Urban and Regional Research, Vol. 32, No. 1, pp. 212223.

Smith, M.K. (2003) 'Issues in cultural tourism studies', London, Routledge.

Smith, V.L. (1989) Hosts and Guests: The Anthropology of Tourism, $2^{\text {nd }}$ edition, Oxford, Blackwell.

Southwest Tourism Report (2008) www.swtourism.org.uk/documents/q/category/financefacts-figures-documents/value-of-tourism-archive/value-of-tourism-2008/.

Spilannis, I \& Vayanni, H (2004) 'Sustainable Tourism: Utopia or Necessity? The Role of New Forms of Tourism in the Aegean Islands' in B. Bramwell (ed.) Coastal Mass Tourism: Diversification and Sustainable Development in Southern Europe, Clevedon, Channel View, pp. 269-291.

Strapp, J.D. (1988) 'The Resort Cycle and Second Homes', Annals of Tourism Research, Vol. 15, No. 4, pp. 504-516. 
UK Average Property Price Calculator

http://news.bbc.co.uk/1/shared/spl/hi/in_depth/uk house prices/html/houses.stm.

Van Ginkel, R. (1995) “Texelian at Heart': The Articulation of Identity in a Dutch Island Society’, Ethnos, Vol. 60, Nos. 3\&4, pp. 265-286.

Wesley, A. \& Pforr, C. (2010) 'The Governance of Coastal Tourism: Unravelling the Layers of Complexity at Smiths Beach, Western Australia'. Journal of Sustainable Tourism, Vol. 18, No. 6, pp. 773-792.

Western Isles Demographic Data (2011)

www.cne-siar.gov.uk/factfile/population/index.asp.

Wilkinson, P.F. (1987) 'Tourism in Small Island Nations: A Fragile Dependence', Leisure Studies, Vol. 2, No. 2, pp. 127-146.

Yin, R. (2003) Applications of Case Study Research, $2^{\text {nd }}$ Edition, Thousand Oaks CA, Sage. 


\section{Appendix A: Discussion Guide}

Could you tell me a little bit about your experiences of living/growing up on the Isle of Man?

Could you tell me about your educational/work experience?

Can you describe for me why you have chosen to live on the Isle of Man/move abroad?

What are the positive and negative consequences of this decision?

Where do you think you will be living in five or so year's time?

Do you have any plans to move in the future - why?

What are the positive things about where you live at present?

And what are the negative?

Can you describe to me your current living arrangements/accommodation?

Positives/negatives?

Is the Isle of Man a good place for young adults?

Why/Why not?

Comments on employment, facilities, social life, housing?

What do you think about the price of property on the Isle of Man?

Compared to the UK?

How do you think prices affect young people, if at all?

How do you think prices affect life on the island - quality of life, environment, etc.?

Do people benefit from current property prices?

Who do you think is responsible for property prices? 